\title{
Cien años de historia
}

Cien años de vida de la Clínica Guayaquil, es traer a la memoria recuerdos y evocaciones que destacan los méritos y virtudes de una institución que ha sobresalido por su proyección social y humana, es tratar de precisar con propiedad la razón de ser de una de las entidades médicas más significativas del país, exponer sus cualidades y sus logros, es escribir la historia de nuestra ciudad y del Ecuador.

De una estirpe de médicos que se inicia desde comienzos del siglo pasado con el Dr. Guillermo Gilbert se proyecta en la vida con su hijo, el eximio cirujano, Dr. Abel Gilbert Pontón, quien se caracterizó por servir a sus semejantes con sus éxitos quirúrgicos aunada a la taumaturgia de sus manos. En su cátedra enseñaba ciencia y nobleza, fue el fundador de esta centenaria institución y dejó su impronta como Vicepresidente de la República, en aquellos años en los que el honor y la dignidad de los ciudadanos era condición indiscutible de sus magistrados.

Su hijo el Dr. Roberto Gilbert Elizalde hereda la responsabilidad de continuar y desarrollar lo iniciado por su padre. De espíritu científico inquieto asombra a sus colegas con sus conocimientos y habilidades quirúrgicas con una especial inclinación a la cirugía cardiaca. Fue el primero en cerrar un ductus arterioso permeable, en operar a "cielo cerrado" una válvula mitral estenosada, en corregir una coartación de la aorta.

En la Clínica Guayaquil se usa por vez primera en el país el MORCH Respirator, uno de los primeros respiradores que se fabricaron en el mundo salvando con esto muchas vidas. En uno de sus viajes trae el primer riñón artificial que se usó en el Ecuador.

Un 13 de febrero de 1964 asombra al mundo médico con el trasplante de un brazo cercenado de un cabo de la Armada Ecuatoriana por el de un cadáver, iniciando así la era de los trasplantes que, posteriormente continuará con la cirugía de trasplantes de riñón, corazón y pulmones, de hígado, etc.

En su afán de iniciar la cirugía cardiaca, se efectúan en perros las primeras cirugías experimentales usando una máquina de circulación extracorpórea de Lillehei-De Wall con un oxigenar de membrana Pulmo-Pack que había sido desarrollado para el grupo de Wangesnsteen de Minneapolis. Finalmente, iniciará en 1969 la cirugía de corazón abierto con la colaboración de George P. Noon y su grupo del Hospital Metodista de Houston, Texas, por primera vez en humanos, en la Clínica Guayaquil.

En la cátedra universitaria es el Maestro de cirugía, orador académico, planifica y organiza, en los años setenta, un Congreso Médico al que asiste lo más distinguido de la cirugía cardiaca, Dr. Michael E. DeBakey de Houston, Texas; John L. Ochsner de New Orleans, el Dr. Eurípides Zerbini de Brasil, George P. Noon del Hospital Metodista de Texas, y muchos otros eminentes cirujanos cardiovasculares. Fue un congreso de estrellas.

Me llamó un día en el mes de mayo de 1966 para atender a una mujer de 18 años procedente de Machala con antecedentes de pérdida de conocimiento y convulsiones, en la que encontramos una frecuencia cardiaca muy lenta, era un síndrome de Stokes-Adams. En sus exámenes

https://doi.org/10.51597/rmicg.v1i1.59 
se diagnostica enfermedad de Chagas. Con el diagnóstico de bloqueo AV completo y, después de estudiar minuciosamente las posibilidades de tratamiento, la única solución era la implantación de un estimulador eléctrico cuyo uso se iniciaba en el mundo entero. Inmediatamente, se contactó con una de sus amistades médicas en el exterior y, a la semana, tenía en sus manos el primer marcapasos de marca Telectronics y un catéter endocárdico.

Noches de estudio y de repasar la técnica recomendada por los pioneros, en la consulta y en el domicilio del Doctor Gilbert, antes de proceder a su implantación. No existía intensificador de imágenes y debimos hacerlo con un equipo de fluoroscopia de la Clínica. Yo había adquirido experiencia en el manejo de catéteres diagnósticos cuando trabajé en la Clínica Shaio de Bogotá, pero esto era totalmente diferente. Con bastante dificultad, y con el respeto que infunde lo desconocido en medicina, fue ubicado el catéter en el ápex de ventrículo derecho y conectado al marcapasos que funcionó desde el primer momento para satisfacción de la paciente y nuestra.

Su caso fue presentado en la Sociedad de Cardiología como el primer implante de marcapasos cardiaco en el Ecuador, y posteriormente con dos casos más, fue publicado en la Gaceta Médica Volumen XXIV de la Sociedad Médico-Quirúrgica del Guayas. Después de muchos años, en el Congreso de la European Society of Cardiology en el año 2015 en Niza, se hace un reconocimiento de los primeros cincuenta implantes en el mundo y constan, de Guayaquil - Ecuador, Gilbert y Alvarado en 1966.

Le corresponde ahora a Roberto Gilbert Febres Cordero continuar con la brillante trayectoria de su señor padre, de hecho, lo ha conseguido con creces, en especial con la cirugía cardiaca, convirtiendo a la Clínica en referente nacional de ella. Pero continúa con las nuevas generaciones y sus colaboradores que seguirán engrandeciendo a la Institución con una distinción especial, la más antigua en su fundación y la más moderna en sus realizaciones.

Lelio Alvarado Villavicencio 